\title{
Towards Post-National and Denationalized Citizenship
}

\author{
SASKIA SASSEN
}

Most of the scholarship on citizenship has claimed a necessary connection to the national state. The transformations afoot today raise questions about this proposition in so far as they significantly alter those conditions which in the past fed that articulation between citizenship and the national state. If this is indeed the case, then we need to ask whether national conceptions of citizenship deserve the presumptions of legitimacy and primacy that they are almost always granted. This chapter interrogates the validity of this presumption and in so doing underlines the historicity of both the institution of citizenship and that of national state sovereignty. It is becoming evident today that far from being unitary, the institution of citizenship has multiple dimensions, only some of which might be inextricably linked to the national state. This chapter discusses the rapidly growing literature that is documenting and conceptualizing these issues, with particular attention to post-national conceptions of citizenship.

The context for this possible transformation is defined by two major, partly interconnected conditions. One is the change in the position and institutional features of national states since the 1980 s resulting from various forms of globalization. These range from economic privatization and deregulation to the increased prominence of the international human rights regime. The second is the emergence of multiple actors, groups and communities partly strengthened by these transformations in the state and increasingly unwilling to automatically identify with a nation as represented by the state. The growth of the Internet and linked technologies has facilitated and often enabled the formation of cross-border networks among individuals and groups with shared interests that may be highly specialized, as in professional networks, or involve particularized political projects, as in human rights and environmental struggles. This has engendered or strengthened alternative notions of community of membership. These new experiences and orientations of citizenship may not necessarily be new; in some cases they may well be the result of long gestations or features that were there since the beginning of the formation of citizenship as a national institution, but are only now evident because enabled by current developments.

One of the implications of these developments is the possibility of post-national forms of citizenship (Soysal, 1994; Jacobson, 1996; Feldblum, 1998; see multiple chapters in Isin, 2000). The emphasis in this formulation is on the emergence of locations for citizenship outside the confines of the national state. The European 
passport is, perhaps, the most formalized of these. But the emergence of a reinvigorated cosmopolitanism (Turner, 2000; Nussbaum, 1998) and of a proliferation of transnationalisms (M. Smith and Guarnizo, 1998; R. Smith, 1997; Basch et al., 1994) have been key sources for notions of post-national citizenship. As Bosniak (2000) has put it, there is a reasonable case to be made that the experiences and practices associated with citizenship do, in variable degrees, have locations that exceed the boundaries of the territorial nation-state. Whether it is the organization of formal status, the protection of rights, citizenship practices, or the experience of collective identities and solidarities, the nation-state is not the exclusive site for their enactment. It remains by far the most important site, but the transformations in its exclusivity signal a possibly important new dynamic.

A second dynamic is becoming evident which, while sharing aspects with postnational citizenship, is usefully distinguished from it in that it concerns specific transformations inside the national state which directly and indirectly alter specific aspects of the institution of citizenship. These transformations are not predicated necessarily on a relocating of citizenship components outside the national state, as is key to conceptions of post-national citizenship. Changes in the law of nationality entailing a shift from purely formal to effective nationality, and enabling legislation allowing national courts to use international instruments, are two instances that capture some of these transformations inside the national state. More encompassing changes, captured in notions of privatization and shrinking welfare states, signal a shift in the relationship of citizens to the state. These and other developments all point to impacts on citizenship that take place inside formal institutions of the national state. It is useful to distinguish this second dynamic of transformation inside the national state because most of the scholarship on these issues is about post-national citizenship and has either overlooked these trends or interpreted them as post-national. In my own work
(Sassen, 1996, 2002) I have conceptualized these trends as a denationalizing of particular aspects of citizenship to be distinguished from post-national developments. I return to this in a later section.

\section{CITIZENSHIP AND NATIONALITY}

In its narrowest definition citizenship describes the legal relationship between the individual and the polity. This relation can in principle assume many forms, in good part depending on the definition of the polity. In Europe this definition of the polity was originally the city, both in ancient and in medieval times. But the configuration of a polity reached its most developed form in the national state, making it eventually a dominant form worldwide. It is the evolution of polities along the lines of state formation that gave citizenship in the West its full institutionalized and formalized character and that made nationality a key component of citizenship.

Today the terms citizenship and nationality both refer to the national state. In a technical legal sense, while essentially the same concept, each term reflects a different legal framework. Both identify the legal status of an individual in terms of state membership. But citizenship is largely confined to the national dimension, while nationality refers to the international legal dimension in the context of an interstate system. The legal status entails the specifics of whom the state recognizes as a citizen and the formal basis for the rights and responsibilities of the individual in relation to the state. International law affirms that each state may determine who will be considered a citizen of that state. ${ }^{1}$ Domestic laws about who is a citizen vary significantly across states and so do the definitions of what it entails to be a citizen (see various chapters in this volume). Even within Europe, let alone worldwide, there are marked differences in how citizenship is articulated and hence how non-citizens are defined.

To understand the nature of the transformations we seek to capture through terms 
such as post-national and denationalized citizenship it is helpful to situate the nationalizing of citizenship. The shift of citizenship into a national state institution and away from one centred in cities and civil society was part of a larger dynamic of change. Key institutional orders began to scale at the national level: warfare, industrial development, educational and cultural institutions. These were all at the heart of the formation and strengthening of the national state as the key political community and crucial to the socialization of individuals into national citizenship. It is in this context that nationality becomes a central constitutive element of the institution of citizenship in a way that it was not in the medieval cities described by Weber.

The evolution of the meaning of nationality captures some of these transformations. Historically, nationality is linked to the bond of allegiance of the individual to the sovereign. It dates from the European state system even in some of its earliest elementary forms and describes the inherent and permanent bond of the subject to the sovereign. 'No man may abjure his country.' Traditionally this bond was seen as insoluble or at least exclusive. But while the bond of insoluble allegiance was defensible in times of limited individual mobility, it became difficult in the face of large-scale migration which was part of the new forms of industrial development. Insoluble was gradually replaced by exclusive, hence singular but changeable, allegiance as the basis of nationality. Where the doctrine of insoluble allegiance is a product of medieval Europe, the development of exclusive allegiance reflects the political context in the second half of the nineteenth century. This is when state sovereignty becomes the organizing principle of an international system - albeit a system centred on and largely ruled by Europe. ${ }^{2}$

Dual nationality was incompatible with the absolute authority of the state over its territory and its nationals (Brubaker, 1989). Indeed, we see the development of a series of mechanisms aimed at preventing or counteracting the occurrence of defacto dual nationality, such as the redrawing of borders after wars or the imposition of a new nationstate on an underlying older one (Marrus, 1985). There were no international accords on dual nationality, a sharp contrast with the 1990s, which have seen a proliferation of such accords. This negative perception of dual nationality continued into the first half of the twentieth century and well into the 1960s. The main effort by the international system was to root out the causes of dual nationality by means of multilateral codification of the law on the subject (Rubenstein, and Adler, 2000).

The major transformations over the last two decades have once again brought conditions for a change in the institution of citizenship and its relation to nationality, and they have brought about changes in the legal content of nationality. It is probably the case that the particular form of the institution of citizenship centred on exclusive allegiance reached its high point in the twentieth century and has, over the last decade, begun to incorporate formal and non-formal qualifications that contribute to dilute that particular formalization. The development in international law of nationality has moved to more flexible forms. The long-lasting resistance to dual or multiple nationality is shifting towards a selective acceptance. According to some legal scholars (Rubenstein, and Adler, 2000), in the future dual and multiple nationality will become the norm. Today more people than ever before hold dual nationality (Spiro, 1997). For Spiro this possibility of multiple allegiances indicates that national citizenship might be less important than it once was. ${ }^{3}$ In so far as the importance of nationality rests on the central role of states in the international state system, a decline in the importance of this role and of this system will affect the value of nationality. This would parallel the devaluation of nation-state-based sovereignty (Sassen, 1996: Ch. 1).

Some of the major transformations occurring today under the impact of globalization may give citizenship yet another set of features as it continues to respond to the conditions within which it is embedded. The nationalizing of the institution which took 
place over the last several centuries may today give way to a partial denationalizing. A fundamental dynamic in this regard is the growing articulation of globalization with national economies and the associated withdrawal of the state from various spheres of citizenship entitlements. One could posit that this thinning if not decline of Marshall's concept of evolving citizenship towards social rights raises the possibility of a corresponding dilution of loyalty to the state. In turn, citizens' loyalty may be less crucial to the state today than it was at a time of intense warfare and its need for loyal citizensoldiers (Turner, 2000). ${ }^{4}$ Masses of troops today can be replaced by technologically intensive methods of warfare. In the highly developed world, warfare has become a less significant event partly due to economic globalization, that is to say, the fact that crucial economic systems and dynamics scale at the global level. One key aspect is the impact of increasingly strong supranational institutions that challenge the authority of nationstates; the EU, IMF, World Bank, WTO, and other such supranational institutions can determine key features of domestic economic performance. Global firms and global markets do not want the rich countries to fight wars among themselves. The 'international' project is radically different from what it was in the nineteenth and first half of the twentieth centuries.

\section{DECONSTRUCTING CITIZENSHIP}

Though often talked about as a single concept and experienced as a unitary institution, citizenship actually describes a number of discrete but related aspects in the relation between the individual and the polity. Current developments are bringing to light and accentuating the distinctiveness of these various aspects, from formal rights to practices and psychological dimensions. These developments also bring to the fore the tension between citizenship as a formal legal status and as a normative project or an aspiration. Current conditions have led to a growing emphasis on claims and aspirations that go beyond the formal legal definition of rights and obligations. Most recently there has also been a reinvigoration of theoretical distinctions: communitarian and deliberative, republican and liberal.

Yet more often than not the nation-state is the typically implicit frame within which these distinctions are explored. In this sense, much of this literature cannot be read as post-national even when it seeks to locate citizenship in areas that go beyond the formal political domain. Nonetheless, this deconstruction of citizenship has also fed a much smaller but growing scholarship which begins to develop notions of citizenship not based on the nation-state, whether understood in narrow political terms or broader sociological and psychological terms. The growing prominence of the international human rights regime has played an important theoretical and political role in strengthening post-national conceptions even as it has underlined the differences between citizenship rights and human rights.

Recently there have been several efforts to organize the various understandings of citizenship one can find in the scholarly literature: citizenship as legal status, as possession of rights, as political activity, as a form of collective identity and sentiment. (Kymlicka and Norman, 1994; Carens, 1996-7; Kratochwil, 1994; Vogel and Moran, 1991; Conover, 1995; Bosniak, 2000). Further, some scholars (Turner, 1994; Taylor, 1994; see also generally van Steenbergen, 1994) have posited that cultural citizenship is a necessary part of any adequate conception of citizenship, while others have insisted on the importance of economic citizenship (Fernandez Kelly, 1993) and yet others on the psychological dimension and the ties of identification and solidarity we maintain with other groups in the world (Conover, 1995; Carens, 1996; Pogge, 1992).

It is important to recognize that while many of these distinctions deconstruct the 
category of citizenship and hence are helpful for formulating novel conceptions, they do not necessarily cease to be nationstate-based. For the development of notions of post-national citizenship it is important to question the assumption that people's sense of citizenship in liberal democratic states is fundamentally characterized by nation-based frames. These questions of identity need to be taken into account along with formal developments such as European Union citizenship and the growth of the international human rights regime. In so far as legal and formal developments have not gone very far, a focus on experiences of identity emerges as crucial to post-national citizenship. ${ }^{5}$

The scholarship that critiques the assumption that identity is basically tied to a national polity can range over a broad range of positions, many having little to do with a post-national conception. For some, the focus is on the fact that people often maintain stronger allegiances to and identification with particular cultural and social groups within the nation than with the nation at large (Young, 1990; Taylor, 1994). Others have argued that the notion of a national identity is based on the suppression of social and cultural differences (Friedman, 1989). These and others have called for a recognition of differentiated citizenship and incorporation not only as individuals but through cultural groups (Young, 1990; Kymlicka and Norman, 1994; Taylor, 1994; Conover, 1995). As Torres (1998) has observed, the 'cultural pluralist' (Kymlicka and Norman, 1994) or multiculturalist positions (Spinner-Halev, 1994) do posit alternatives to a 'national' sense of identity, yet continue to use the nation-state as the normative frame and to understand the social groups involved as parts of national civil society. This holds also for proposals to democratize the public sphere through multicultural representation (Young, 1990; Kymlicka, 1995) since the public sphere is thought of as national. Bosniak (2000) observes that they reject notions of citizenship as unitary, but the fragments continue to be located within national boundaries.
Clearly, some of these critical literatures do not actually go beyond the nation-state and thereby do not fit into post-national conceptions of citizenship, even though they may fit into a conception of citizenship as partly or increasingly denationalized.

Critical challenges to statist premises can also be found in concepts of local citizenship, typically at the urban level (e.g. Magnusson, 1990, 2000; Isin, 2000), or by reclaiming domains of social life, often excluded from conventional conceptions of politics, as sites for citizenship. Examples of the latter focus on recognition of citizenship practices in the workplace (Pateman, 1989), in the economy at large (Dahl, 1989), in the family (Jones, 1998), in new social movements (Tarrow, 1994; Magnusson, 2000). These are more sociological versions of citizenship not confined by narrowly defined formal political grounds for citizenship. Again, most of the literature on civil society is nationally demarcated. As for the literature on local citizenship, it contains important indications of trends that are of interest to post-national and denationalized conceptions of citizenship, as discussed in a later section.

Partly influence by these various critical literatures and partly originating in other fields, there is a rapidly growing literature today that is beginning to elaborate notions of transnational civil society and citizenship. It focuses on new transnational forms of political organization emerging in a context of rapid globalization and proliferation of transnational activity through NGOs (Smith and Guarnizo, 1998; Keck and Sikkink, 1998; Bonilla et al., 1998; Wapner, 1994). It focuses on cross-border struggles around human rights, the environment, arms control, women's rights, labor rights, rights of national minorities. For Falk (1993) these are citizen practices that go beyond the nation. Transnational activism emerges as a form of global citizenship which Magnusson (1994: 103) describes as 'popular politics in its global dimension.' Wapner (1995: 312-13) captures these emergent forms of civil society as 'a slice of associational life 
which exists above the individual and below the state, but also across national boundaries.'

A growing number of scholars concerned with identity and solidarity posit the rise of transnational identities (Torres, 1998; Cohen, 1996; Franck, 1997) and translocal loyalties (Appadurai, 1996: 165). Bosniak (2000: 482) finds at least four forms taken by transnationalized citizenship identity claims. One is the growth of Europe-wide citizenship said to be developing as part of the EU integration process, and beyond the formal status of EU citizenship (Soysal, 1994; Howe, 1991; Isin, 2000a: 1-22; Delanty, 2000). Turner has posited a growing cultural awareness of a 'European identity' (2000). A second focus is on the affective connections that people establish and maintain with one another in the context of a growing transnational civil society (Cohen, 1995; Lipschutz, 1996; Lister, 1997). Citizenship here resides in identities and commitments that arise out of crossborder affiliations, especially those associated with oppositional politics (Falk, 1993), though it might include the corporate professional circuits that are increasingly forms of partly deterritorialized global cultures (Sassen, 2001).

A third version is the emergence of transnational social and political communities constituted through transborder migration. These begin to function as bases for new forms of citizenship identity to the extent that members maintain identification and solidarities with one another across state territorial divides (Portes, 1996; Basch et al., 1994; R. Smith, 1997; M. Smith and Guarnizo, 1998; Soysal, 1997). These are, then, citizenship identities that arise out of networks, activities, ideologies that span the home and the host society (Basch et al., 1994). A fourth version is a sort of global sense of solidarity and identification, partly out of humanitarian convictions (Slawner and Denham, 1998; Pogge, 1993). Notions of the ultimate unity of human experience are part of a long tradition. Today there are also more practical considerations at work, as in global ecological interdependence, economic globalization, global media and commercial culture, all of which create structural interdependencies and senses of global responsibility (Falk, 1993; Hunter, 1992; Held, 1998; Sassen, 1996).

\section{TOWARDS EFFECTIVE NATIONALITY AND INFORMAL CITIZENSHIP}

Some of these issues can be illustrated by two contrasting cases forms of local citizenship.

\section{Unauthorized Yet Recognized}

Perhaps one of the more extreme instances of a condition akin to effective as opposed to formal nationality is what has been called the informal social contract that binds undocumented immigrants to their communities of residence (Schuck and Smith, 1985). Thus, unauthorized immigrants who demonstrate civic involvement, social deservedness, and national loyalty can argue that they merit legal residency. To make this brief examination more specific, I will focus on one case, undocumented immigrants in the USA. Individuals, even when undocumented immigrants, can move between the multiple meanings of citizenship. The daily practices by undocumented immigrants as part of their daily life in the community where they reside (raising a family, schooling children, holding a job) earn them citizenship claims in the USA even as the formal status and, more narrowly, legalization may continue to evade them. Certain dimensions of citizenship, such as strong community ties and participation in civic activities, are being enacted informally through these practices. These practices produce an at least partial recognition of the individuals as full social beings. In many countries around the world, including the USA, long-term undocumented residents often can gain legal residence if they can document the fact of this long-term residence and 'good conduct.' US immigration 
law recognizes such informal participation as grounds for granting legal residency. For instance, prior to the new immigration law passed in 1996, individuals who could prove seven years of continuous presence and good moral character, and that deportation would be an extreme hardship, were eligible for suspension of deportation, and thus, US residency. NACARA ${ }^{6}$ extended the eligibility of this suspension of deportation to some 300,000 Salvadorans and Guatemalans who were unauthorized residents in the USA.

The case of undocumented immigrants is, in many ways, a very particular and special illustration of a condition akin to 'effective' citizenship and nationality. One way of interpreting this dynamic in the light of the discussion in the preceding sections is to emphasize that it is the fact of the multiple dimensions of citizenship which engenders strategies for legitimizing informal or extrastatal forms of membership (Soysal, 1994; Coutin, 2000). The practices of these undocumented immigrants are a form of citizenship practices and their identities as members of a community of residence assume some of the features of citizenship identities. Supposedly this could hold even in the communitarian model where the community can decide on whom to admit and whom to exclude, but once admitted, proper civic practices earn full membership.

Further, the practices of migrants, even if undocumented, can contribute to recognition of their rights in countries of origin. During the 1981-92 civil war, Salvadoran migrants, even though citizens of Salvador, were directly and indirectly excluded from El Salvador through political violence, enormous economic hardship, and direct persecution (Mahler, 1995). They could not enjoy their rights as citizens. After fleeing, many continued to provide support to their families and communities. Further, migrants' remittances became a key factor for EL Salvador's economy - as they are for several countries around the world. The government of EL Salvador actually began to support the emigrants, fight to obtain residency rights in the USA, even though they were joining
US-based activist organizations in this effort. The Salvadoran government was thus supporting Salvadorans who were formerly excluded citizens - they needed those remittances to keep coming and they needed the emigrants to stay out of the Salvadoran workforce, given high unemployment. Thus the participation of these undocumented migrants in cross-border community, family and political networks has contributed to increasing recognition of their legal and political rights as Salvadoran citizens (Coutin, 2000; Mahler, 1995; see Sassen, 2002 for the case of several other countries).

According to Coutin (2000) and others, movements between membership and exclusion, and between different dimensions of citizenship, legitimacy and illegitimacy, may be as important as redefinitions of citizenship itself. Given scarce resources, the possibility of negotiating the different dimensions of citizenship may well represent an important enabling condition. Undocumented immigrants develop informal, covert, often extrastatal strategies and networks connecting them with communities in sending countries. Home towns rely on their remittances and their information about jobs in the USA. The sending of remittances illegally by an unauthorized immigrant can be seen as an act of patriotism, and working as an undocumented immigrant can be seen as contributing to the host economy. Multiple interdependencies are thereby established and grounds for claims on the receiving and the originating country can be established even when the immigrants are undocumented and laws are broken (Basch et al., 1995; R. Smith, 1997).

\section{Authorized yet Unrecognized}

At perhaps the other extreme of the undocumented immigrants whose practices allow them to become accepted as members of the political community is the case of those who are full citizens yet not recognized as political subjects. In an enormously insightful study of Japanese housewives, LeBlanc finds precisely this combination. 
Being a housewife is basically a full-time occupation in Japan and restricts Japanese women's public life in many important ways, both practical and symbolic. The very identity of a 'housewife' in Japan is customarily that of a particularistic, non-political actor. Yet, paradoxically, the condition of being a 'housewife' provides these women with a unique vehicle for other forms of public participation, ones where being a housewife is an advantage, ones denied to those who might have the qualifications of higher-level political life. LeBlanc documents how the housewife has an advantage in the world of local politics or the political life of a local area: she can be trusted precisely because she is a housewife, she can build networks with other housewives, hers is the image of desirable public concern and of a powerful, because believable, critique of mainstream politics.

There is something extremely important in this condition which is shared with women in other cultures and vis à vis different issues. For instance, and in a very different register, women emerged as a specific type of political actor during the brutal dictatorships of the 1970s and 1980s in several countries of Latin America. It was precisely their condition as mothers and wives which gave them the clarity and the courage to demand justice and to demand bread and to do so confronting armed soldiers and policemen. Mothers in the barrios of Santiago during Pinochet's dictatorship, the mothers of the Plaza de Mayo in Buenos Aires, the mothers regularly demonstrating in front of the major prisons in EL Salvador during the civil war - all were driven to political action by their despair at the loss of children and husbands and the struggle to provide food in their homes.

Further, and in a very different type of situation, there is an interesting parallel between LeBlanc's capturing of the political in the condition of the housewife and a set of findings in some of the research on immigrant women in the USA. There is growing evidence that immigrant women's regular wage work and improved access to other public realms has an impact on their culturally specified subordinate role to men in the household. Immigrant women gain greater personal autonomy and independence, while immigrant men lose ground compared to their condition in cultures of origin. Women gain more control over budgeting and other domestic decisions, and greater leverage in requesting help from men in domestic chores. Also, their access to public services and other public resources gives them a chance to become incorporated into the mainstream society - they are often the ones in the household who mediate in this process. It is likely that some women benefit more than others from these circumstances; we need more research to establish the impact of class, education and income on these gendered outcomes.

Besides the relatively greater empowerment of immigrant women in the household associated with waged employment, there is a second important outcome: their greater participation in the public sphere and their possible emergence as public actors. Immigrant women are active in two arenas: institutions for public and private assistance, and the immigrant/ethnic community. The incorporation of women into the migration process strengthens the likelihood of settlement and contributes to greater immigrant participation in their communities and vis à vis the state. For instance, HondagneuSotelo (1995) found immigrant women come to assume more active public and social roles, which further reinforces their status in the household and the settlement process. These immigrant women are more active in community-building and community activism and they are positioned differently from men regarding the broader economy and the state. They are the ones that are likely to have to handle the legal vulnerability of their families in the process of seeking public and social services for their families. This greater participation by women suggests that they may emerge as more forceful and visible actors and make their role in the labor market more visible as well. 
These are dimensions of citizenship and citizenship practices which do not fit the indicators and categories of mainstream frameworks for understanding citizenship and political life. Women in the condition of housewives and mothers do not fit the categories and indicators used to capture participation in public life. Feminist scholarship in all the social sciences has had to deal with a set of similar or equivalent difficulties and tensions in its effort to constitute its subject or to reconfigure a subject that has been flattened. The theoretical and empirical distance that has to be bridged between the recognized world of politics and the as yet unmapped experience of citizenship of the housewife - not of women as such, but of women as housewives - is a distance we encounter in many types of inquiry. Bridging this distance entails both an empirical research strategy and a theorization.

\section{Forms of Local Citizenship?}

There is something to be captured here - a distinction between powerlessness and the condition of being an actor even though lacking power. I use the term presence to name this condition. In the context of a strategic space such as the global city, the types of disadvantaged people described here are not simply marginal; they acquire presence in a broader political process that escapes the boundaries of the formal polity. This presence signals the possibility of a politics. What this politics will be will depend on the specific projects and practices of various communities. In so far as the sense of membership of these communities is not subsumed under the national, it may well signal the possibility of a transnational politics centred in concrete localities.

The large city of today emerges as a strategic site for these new types of operations. It is one of the nexuses where the formation of new claims materializes and assumes concrete forms. The loss of power at the national level produces the possibility for new forms of power and politics at the subnational level. The national as container of social process and power is cracked. This cracked casing opens up possibilities for a geography of politics that links subnational spaces. These dynamics are perhaps sharpest in global cities around the world. They are the terrain where a multiplicity of globalization processes assume concrete, localized forms. These localized forms are, in good part, what globalization is about. Thus they are also sites where some of the new forms of power can be engaged. If we consider that cities concentrate both the leading sectors of global capital and a growing share of disadvantaged populations - immigrants, many of the disadvantaged women, people of colour generally, and, in the megacities of developing countries, masses of shanty dwellers - then we can see that cities have become a strategic terrain for a whole series of conflicts and contradictions.

The conditions that today make it possible for certain kinds of cities to emerge as strategic sites are basically two, and both capture major transformations that are destabilizing older systems organizing territory and politics. One of these is the re-scaling of the strategic territories that articulate the new politico-economic system. The other is the partial unbundling or at least weakening of the national as container of social process due to the variety of dynamics encompassed by globalization, including digitization. The consequences for cities of these two conditions are many: what matters here is that cities emerge as strategic sites for major economic processes and that new types of political actors can emerge. In so far as citizenship is embedded and in turn marked by its embeddedness, these new conditions may well signal the possibility of new forms of citizenship practices and identities.

These citizenship practices have to do with the production of 'presence' of those without power and a politics that claims rights to the city. Through these practices new forms of citizenship are taking shape, with the city as a key site for this type of political work and, indeed, itself partly shaped through these dynamics. After the 
long historical phase that saw the ascendance of the national state and the scaling of key economic dynamics at the national level, the city - a strategic scale for citizen actors - is once again today a scale for strategic economic and political dynamics.

\section{POST-NATIONAL OR DENATIONALIZED?}

In my reading we are dealing with two distinct dynamics rather than only the emergence of locations for citizenship outside the frame of the national state. I distinguish what I would narrowly define as denationalized from post-national, the latter being the term most commonly used and the only one used in the broader debate. It is precisely in the differences between these dynamics that I see the potential for capturing two, not necessarily mutually exclusive, possible trajectories for the institution of citizenship.

Their difference is a question of scope and institutional embeddedness. The understanding in the scholarship is that post-national citizenship is located partly outside the confines of the national. ${ }^{7}$ I argue that in considering denationalization, the focus moves on to the transformation of the national, including the national in its condition as foundational for citizenship. Thus it could be argued that post-nationalism and denationalization represent two different trajectories. Both are viable, and they do not exclude each other. One has to do with the transformation of the national, specifically under the impact of globalization and several other dynamics, and will tend to instantiate inside the national. The other has to do with new forms that we have not even considered and might emerge out of the changed conditions in the world located outside the national rather than out of the earlier institutional framework of the national. Thus Soysal's focus on the European Union is capturing an innovation located outside the national.
With denationalization I seek to capture something that remains connected to the national, as constructed historically, and is indeed profoundly imbricated with it but is so on what we can define as historically new terms of engagement. Incipient and partial are two qualifiers I usually attach to my use of denationalization. Let me elaborate.

From the perspective of nation-based citizenship theory, some of these transformations might be interpreted as a decline or devaluation of citizenship or, more favourably, as a displacement of citizenship in the face of other forms of collective organization and affiliation, as yet unnamed (Bosniak, 2000). In so far as citizenship is theorized as necessarily national, by definition these new developments cannot be captured in the language of citizenship. An alternative interpretation is to suspend the national, as in post-national conceptions, and to posit that the issue of where citizenship is enacted is one to be determined in light of developing social practice (e.g. Soysal, 1994; Jacobson, 1996).

From where I look at these issues, there is a third possibility, beyond these two. It is that citizenship, even if situated in institutional settings that are 'national' is a possibly changed institution if the meaning of the national itself has changed. In so far as globalization has changed certain features of the territorial and institutional organization of the state, the institution of citizenship its formal rights, its practices, its psychological dimension - has also been transformed even when it remains centred in the national state, i.e. barring post-national versions of citizenship. I have argued, for instance, that this territorial and institutional transformation of state power and authority has produced operational, conceptual and rhetorical openings for nation-based subjects other than the national state to emerge as legitimate actors in international/global arenas that used to be confined to the state. (See Indiana Journal of Global Legal Studies, 1996.)

The national remains a referent in these cases. But, clearly, it is a referent of a specific sort: it is, after all, the change of the 
national that becomes the key theoretical feature through which it enters the specification of changes in the institution of citizenship. Whether this does or does not devalue citizenship (cf. Jacobson, 1996) is not immediately evident to me at this point, partly because the institution of citizenship has undergone many transformations in its history (Turner, 1993) and is to variable extents embedded in the specifics of each of its eras. ${ }^{8}$

This pluralized meaning of citizenship, partly produced by the formal expansions of the legal status of citizenship, is today contributing to explode the boundaries of that legal status even further. One of the ironies is that in so far as the enjoyment of rights is crucial to what we understand citizenship to be, it is precisely the formalized expansion of citizen rights which has weakened the 'national grip' on citizenship. Notable here is also the emergence of the human rights regime partly enabled by national states. Again, from where I look at the question, it seems to me that this transformation in nation-based citizenship is not only due to the emergence of non-national sites for legitimate claim-making, i.e. the human rights regime, as is posited in the postnational conception. I would add two other elements that show that this loosening grip is also related to changes internal to the national state.

First, and most important in my reading, is the strengthening, including the constitutionalizing, of civil rights which allow citizens to make claims against their states and allow them to invoke a measure of autonomy in the formal political arena that can be read as a lengthening distance between the formal apparatus of the state and the institution of citizenship. The implications, both political and theoretical, of this dimension are complex and in the making: we cannot tell what practices and rhetorics might be invented.

Secondly, I add to this the granting, by national states, of a whole range of 'rights' to foreign actors, largely and especially economic actors - foreign firms, foreign investors, international markets, foreign business people (see Sassen, 1996: Ch. 2). Admittedly, this is not a common way of framing the issue. It comes out of my particular perspective about the impact of globalization and denationalization on the national state, including the impact on the relation between the state and its own citizens, and it and foreign actors. I see this as a significant, though not much recognized, development in the history of claim-making. For me the question as to how citizens should handle these new concentrations of power and 'legitimacy' that attach to global firms and markets is a key to the future of democracy. My efforts to detect the extent to which the global is embedded and filtered through the national (e.g. the concept of the global city) is one way of understanding whether there lies a possibility therein for citizens, still largely confined to national institutions, to demand accountability of global economic actors through national institutional channels, rather than having to wait for a 'global' state.

Thus, while I would agree with those who posit that accentuating the national is a handicap in terms of democratic participation in a global age, I would argue that it is not an either-or proposition precisely because of this partial embedding of the global in the national. (See in this regard also Aman, Jr., 1998). There is indeed a growing gap between the globalization of more and more parts of reality and the confinement of the national state to its territory. But it is inadequate to simply accept the prevailing wisdom in this realm which, wittingly or not, presents the national and the global as two mutually exclusive domains for theorization and for politics. I find this a highly problematic proposition even though I recognize that each of these domains has specificity (Sassen, 2002). It is enormously important to develop forms of participatory politics that decentre, and sometimes transcend national political life, and to learn how to practice democracy across borders. In this I fully support the political project of post-national citizenship. I would just add to this that we also can engage in democratic practices that cross borders and engage the 
global from within the national and through national institutional channels.

Two big changes of the last decade, in this regard, are the growing weight of the human rights regime on states under the rule of law and the growing use of human rights instruments in national courts both in interpretation and adjudication. These are instances of denationalization in so far as the mechanisms are internal to the national state national courts and legislatures-while the instruments invoke an authority that transcends the national state and the interstate system. ${ }^{9}$ The long-term persuasive powers of human rights are a significant factor in this context. It is important to note here that the human rights regime, while international, deals with citizens inside a state. It thereby destabilizes older notions of exclusive state sovereignty articulated in international law which posit that matters internal to a country are solely to be determined by the state.

\section{CONCLUSION}

Two aspects emerge as crucial from this analysis. The history of interactions between differential positionings and expanded inclusions signals the possibility that the new conditions of inequality and difference evident today and the new types of claimmaking they produce may well bring about further transformations in the institution. Citizenship is partly produced by the practices of the excluded. Secondly, by expanding the formal inclusionary aspect of citizenship, the national state contributed, perhaps ironically, to creating some of the conditions that eventually would facilitate key aspects of post-national and denationalized citizenship. This again signals the possibility of an expanded arena for postnational and denationalized conceptions of citizenship.

The pressures of globalization on national states may mean that claim-making will increasingly be directed at other institutions as well. This is already evident in a variety of instances. One example is the decision by First Nation people to go directly to the UN and claim direct representation in international fora, rather than going through the national state. And it is evident in the increasingly institutionalized framework of the international human rights regime and the emergent possibilities for bypassing unilateral state sovereignty. For many, citizenship is a normative project whereby social membership becomes increasingly comprehensive and open-ended. Globalization and human rights are further enabling this tension and therewith enabling the elements of a new discourse on rights. Though in very different ways, both globalization and the human rights regime have contributed to destabilizing existing political hierarchies of legitimate power and allegiance over the last decade. These developments raise a fundamental question about what is the analytic terrain within which we need to place the question of rights, authority and obligations of the state and the citizen.

\section{NOTES}

1 Nationality is important in international law in a variety of contexts. Treaties and conventions in turn can impact nationality.

2 This is quite evident in how nationality was conceived. The aggressive nationalism and territorial competition between states in the eighteenth, nineteenth and well into the twentieth centuries made the concept of dual nationality generally undesirable, incompatible with individual loyalties and destabilizing of the international order.

3 Soysal (1994) and Feldblum (1998) interpret the increase in dual nationality in terms of post-national citizenship rather than a mere devaluing of national allegiance. I would argue that it is a partial denationalizing of citizenship.

4 Further, during industrialization, class formation, class struggles, and the advantages of employers or workers tended to scale at the national level and became identified with state-produced legislation and regulations, entitlements and obligations. The state came to be seen as a key to ensuring the well-being of significant portions of both the working class and the bourgeoisie. The development of welfare states in the twentieth century became a crucial institutional domain for granting entitlements to the poor 
and the disadvantaged. Today, the growing weight given to notions of the 'competitiveness' of states puts pressure on states to cut down on these entitlements. This in turn weakens the reciprocal relationship between the poor and the state. Finally, the growth of unemployment and the fact that many of the young are developing weak ties to the labor market, once thought of as a crucial mechanism for the socialization of young adults, will further weaken the loyalty and sense of reciprocity between these future adults and the state (Roulleau-Berger, 2001; Munger, 2001).

5 In this regard, a focus on changes inside the national state and the resulting possibility of new types of formalizations of citizenship status and rights - formalizations that might contribute to a partial denationalizing of certain features of citizenship - should be part of a more general examination of change in the institution of citizenship. Distinguishing post-national and denationalized dynamics in the construction of new components of citizenship allows us to take account of changes that might still use the national frame yet are in fact altering the meaning of that frame. I return to this later.

6 NACARA is the 1997 Nicaraguan Adjustment and Central American Relief Act. It created an amnesty for 300,000 Salvadorans and Guatemalans to apply for suspension of deportation. This is an immigration remedy that had been eliminated by the Illegal Immigration Reform and Immigrant Responsibility Act in 1996 (see Coutin, 2000).

7 See notably Soysal's (1994) trend-setting book; see also Bosniak (2000) who, while using the term denationalized, actually is using it to denote post-national, and it is the post-national concept that is crucial to her critique.

8 In this regard, I have emphasized as significant (Sassen, 1996: Ch. 2) the introduction in the new constitutions of South Africa, Brazil, Argentina and the Central European countries, of a provision that qualifies what had been an unqualified right (if democratically elected) of the sovereign to be the exclusive representative of all its people in international fora. Significant here is also the fact that in many Western-style democracies, the USA especially, it was through national law that many of these inclusions of distinct sectors of the population and their claims were instituted, inclusions which today are destabilizing older notions of citizenship. (For elaborations of these issues see Sassen, 2002).

9 Elsewhere (Sassen, 2002) I examine the case of WTO law along the same lines.

\section{REFERENCES}

Aman, Alfred C. Jr. (1998) 'The Globalizing State: A Future-Oriented Perspective on the Public/Private Distinction, Federalism, and Democracy', Vanderbilt Journal of Transnational Law, 31 (4): 769-870.

Andrews, Geoff (ed.) (1990) Citizenship. London: Lawrence and Wishart.
Appadurai, Arjun (1996) Modernity at Large. Minneapolis: University of Minnesota Press.

Barber, Benjamin (1984) Strong Democracy: Participatory Politics for a New Age. Berkeley: University of California.

Basch, Linda, Glick Schiller, Nina and Szanton-Blanc, Cristina (1994) Nations Unbound: Transnationalized Projects and the Deterritorialized Nation-State. New York: Gordon and Breach.

Bauböck, Rainer (1994) Transnational Citizenship: Memberships and Rights in International Migration. Aldershot, England: Edward Elgar.

Benhabib, Seyla (1998) 'European Citizenship', Dissent, Fall: 107-15.

Bhabha, Jacqueline (1998) "“Get Back to Where You Once Belonged": Identity, Citizenship and Exclusion in Europe', Human Rights Quarterly, 20 (3): 592-627.

Bonilla, Frank, Melendez, Edwin, Morales, Rebecca and Torres, Maria de los Angeles (eds) (1998) Borderless Borders. Philadelphia: Temple University Press.

Bosniak, Linda S. (1992) 'Human Rights, State Sovereignty and the Protection of Undocumented Migrants Under the International Migrant Workers Convention', International Migration Review, xxv (4): 737-70.

Bosniak, Linda S. (2000) 'The State of Citizenship: Citizenship Denationalized', Indiana Journal of Global Legal Studies, 7 (2): 447-510.

Brecher, Jeremy and Costello, Tim (eds) (1993) Global Visions: Beyond the New World Order. Boston: South End Press.

Brodie, Janine (2000) 'Imagining democratic urban citizenship', in Engin Isin (ed.), Democracy, Citizenship and the Global City. London and New York: Routledge, pp. 110-28.

Brubaker, W Rogers (ed.) (1989) Immigration and the Politics of Citizenship. Lanham, New York, and London: University Press of America (with the German Marshall Fund of the USA).

Carens, Joseph H. (1989) 'Membership and Morality: Admission to Citizenship in Liberal Democratic States', in W. Rogers Brubaker (ed.) Immigration and the Politics of Citizenship. Lanham, New York and London: University Press of America, pp. 31-49.

Cohen, Jean (1995) 'Interpreting the Notion of Global Civil Society', in M. Walzer, (ed.)

Cohen, Robin (1996) 'Diasporas and the Nation-State: From Victims to Challenges', International Affairs, 72 (3): 507-21.

Conover, Pamela Johnston (1995) 'Citizen Identities and Conceptions of the Self', Journal of Political Philosophy, 3 (2): 133-66.

Coutin, Susan B. (2000) 'Denationalization, Inclusion, and Exclusion: Negotiating the Boundaries of Belonging', Indiana Journal of Global Legal Studies, 7 (2): 585-94.

Dahl, Robert (1989) Democracy and Its Critics. New Haven: Yale University Press.

Delanty, Gerard (2000) 'The resurgence of the city in Europe?: the spaces of European citizenship', in Engin 
Isin (ed.) Democracy, Citizenship and the Global City. London and New York: Routledge, pp. 79-92.

Drainville, Andre (1995) 'Left Internationalism and the Politics of Resistance in the New World Order', in David A. Smith and Josef Borocs (eds), A New World Order: Global Transformation in the Late Twentieth Century. Westport, CT: Greenwood Press, pp.

Eade, John (ed.) (1996) Living the Global City: Globalization as a Local Process. London: Routledge.

Fagen, Patricia Weiss and Eldridge, Joseph (1991) 'Salvadorean repatriation from Honduras', in Mary Ann Larkin (ed.) Repatriation under Conflict: The Central American Case. Washington DC: HMP, CIPRA, Georgetown University.

Falk, Richard (1989) Revitalizing International Law. Ames: Iowa State University Press.

Falk, Richard (1993) 'The Making of Global Citizenship', in Jeremy, Brecher and Tim Costello (eds), Global Visions: Beyond the New World Order. Boston: South End Press, pp.

Feldblum, Miriam (1998) 'Reconfiguring Citizenship in Western Europe', in Ch. Joppke (ed.), Challenge to the Nation-State. Oxford: Oxford University Press, pp.

Fernandez Kelly, Maria-Patricia (1993) 'Underclass and Immigrant Women as Economic Actors: Rethinking Citizenship in a Changing Global Economy', American University International Law Review, 9 (1).

Franck, Thomas M. (1992) 'The Emerging Right to Democratic Governance', American Journal of International Law, 86 (1): 46-91.

Franck, Thomas M. (1997) 'Community Based on Autonomy', Columbia Journal of Transnational Law, 36: 41-65.

Friedman, Marilyn (1989) 'Feminism and Modern Friendship: Dislocating the Community', Ethics, 99 (2): 275-90.

Guarnizo, Luis E. (1994) 'Los Dominicanyorks: The Making of a Binational Society', Annals, AAPSS, 533 (May): 70-86.

Habermas, Jurgen (1998) The Inclusion of the Other: Studies in Political Theory. Cambridge, MA.: MIT Press.

Haus, Leah (1995) 'Openings in the wall: transnational migrants, labor unions, and U.S. immigration policy', International Organization, 49 (2 Spring): 285-313.

Heisler, Martin (1986) 'Transnational Migration as a Small Window on the Diminished Autonomy of the Modern Democratic State', Annals (American Academy of Political and Social Science), 485 (May): 153-166.

Held, David (1995) Democracy and the Global Order: From the Modern State to Cosmopolitan Governance. Cambridge: Polity Press.

Henkin, Louis (1990) The Age of Rights. New York: Columbia University Press.

Hondagneu-Sotelo, Pierrette (1994) Gendered Transitions. Berkeley: University of California Press.

Howe, Stephen (1991) 'Citizenship in the New Europe', in Geoff Andrews (ed.), Citizenship. London: Lawrence and Wishart, pp. 123-36.
Indiana Journal of Global Legal Studies (1996) Special Issue: Feminism and Globalization: The Impact of The Global Economy on Women and Feminist Theory, 4 (1).

Isbister, John (1996) The Immigration Debate. Remaking America. West Hartford, Conn: Kumarian Books.

Isin, Engin F. (ed.) (2000) Democracy, Citizenship and the Global City. London and New York: Routledge.

Jones, Kathleen B. (1998) 'Citizenship in a Woman Friendly Polity', in Gershon Shafir (ed.), The Citizenship Debates. Minneapolis: University of Minnesota Press, pp. 221-51.

Joppke, Christian (ed.) (1998) Challenge to the NationState. Oxford: Oxford University Press.

Keck, Margaret E. and Sikkink, Kathryn (1998) Activists Beyond Borders: Advocacy Networks in International Politics. Ithaca, NY: Cornell University Press.

Kratochwil, Friedrich (1994) 'Citizenship: On the Border of Order', Alternatives, 19.

Kymlicka, Will (1995) Multicultural Citizenship: A Liberal Theory of Minority Rights. Oxford: Clarendon Press.

Kymlicka, Will and Norman, Wayne (1994) 'Return of the Citizen: A Survey of Recent Work on Citizenship Theory', Ethics, 104 (2): 352-81.

LeBlanc, H. (1997) Bicycle Citizens. Berkeley, CA: University of California Press.

Lister, Ruth (1997) Citizenship: Feminist Perspectives. Basingstoke: Macmillan Press.

Magnusson, Warren (1990) 'The Reification of Political Community', in R.B.J. Walker, and Saul H. Mendlovitz (eds), Contending Sovereignties: Redefining Political Community. Boulder, CO: Rienner, pp. 45-61.

Magnusson, Warren (1996) The Search for Political Space. Toronto: University of Toronto Press.

Magnusson, Warren (2000) 'Politicizing the global city', in Engin, Isin (ed.), Democracy, Citizenship and the Global City. London and New York: Routledge, pp. 289-306.

Mahler, Sarah (1995) American Dreaming: Immigrant Life on the Margins. Princeton, NJ: Princeton University Press.

Mansbridge, Jane (1980) Beyond Adversary Democracy. New York: Basic Books.

Marrus, Michael R. (1985) The Unwanted: European Refugees in the Twentieth Century. New York: Oxford University Press.

Mouffe, Chantal (ed.) (1992) Dimensions of Radical Democracy. London: Verso.

Nussbaum, Martha (1994) 'Patriotism and Cosmopolitanism', Boston Review (October-November).

Ong, Aihwa (1999) Flexible Citizenship. Durham, NC: Duke University Press.

Peterson, Spike (1990) 'Whose Rights? A Critique of the "Givens" in Human Rights Discourse', Alternatives, 15.

Pickus, Noah M.J. (ed.) (1998) Immigration and Citizenship in the Twenty-First Century. Lanham, MD: Rowman and Littlefield. 
Pogge, Thomas (1992) 'Cosmopolitanism and Sovereignty' Ethics 103 (1): 48-75.

Portes, A. (1996) 'Global Villagers: The Rise of Transnational Communities', American Prospect, 7 (25).

Rubenstein, Kim and Adler, Daniel (2000) 'International Citizenship: The Future of Nationality in a Globalized World', Indiana Journal of Global Legal Studies, 7 (2): 519-48.

Sassen, Saskia (1996) Losing Control? Sovereignty in an Age of Globalization. The 1995 Columbia University Leonard Hastings Schoff Memorial Lectures, New York: Columbia University Press.

Sassen, Saskia (2001) The Global City: New York, London, Tokyo. 2nd edition, Princeton, NJ: Princeton University Press.

Sassen, Saskia (2002) De-Nationalization. Princeton, NJ: Princeton University Press.

Schuck, Peter H. and Smith, Rogers M. (1985) Citizenship Without Consent: Illegal Aliens in the American Polity. New Haven: Yale University Press.

Shafir, Gershon (ed.) (1998) The Citizenship Debates. Minneapolis: University of Minnesota Press.

Smith, David A. and Borocs, Josef (eds) (1995) A New World Order: Global Transformation in the Late Twentieth Century. Westport, CT: Greenwood Press.

Smith, Michael Peter and Guarnizo Luis Eduardo (eds) (1998) Transnationalism from Below. New Brunswick, NJ: Transaction Publishers.

Smith, Robert C. (1997) 'Transnational Migration, Assimilation and Political Community', in Margaret Crahan and Alberto Vourvoulias-Bush (eds) The City and the World. NY: Council of Foreign Relations, pp. 110-33.

Soysal, Yasemin Nohuglu (1994) Limits of Citizenship: Migrants and Postnational Membership in Europe. Chicago: University of Chicago Press.

Soysal, Yasemin Nohuglu (1997) 'Changing Parameters of Citizenship and Claims-Making: Organized Islam in European Public Spheres', Theory and Society, 26 (4): 509-27.

Spinner-Halev, Jeff (1994) The Boundaries of Citizenship: Race, Ethnicity, and Nationality in the Liberal State. Baltimore: Johns Hopkins University Press.
Spiro, Peter J. (1997) 'Dual Nationality and the Meaning of Citizenship', Emory Law Journal, 46 (4).

Spiro, Peter J. (1999) 'The Citizenship Dilemma' Stanford Law Review, 51, 3.

Staeheli, Lynn A. (1999) 'Globalization and the scales of citizenship', Geography Research Forum, 19: 60-77 (special Issue On Geography and the Nation-State, edited by Dennis Pringle and Oren Yiftachel).

van Steenbergen, Bart (ed.) (1994) The Condition of Citizenship. London: Sage Publications.

Tarrow, Sydney (1994) Power in Movement: Social Movements, Collective Action and Politics. Cambridge: Cambridge University Press.

Taylor, Charles (1994) 'The Politics of Recognition', in Amy, Gutmann (ed.) Multiculturalism: Examining the Politics of Recognition. Princeton: Princeton University Press, pp. 25-75.

Torres, Maria de los Angeles (1998) 'Transnational Political and Cultural Identities: Crossing Theoretical Borders', in Frank Bonilla, Edwin Melendez, Rebecca Morales and Maria de los Angeles Tornes (eds), Borderless Borders. Philadelphia: Temple University Press.

Turner, Bryan S. (ed.) (1993) Citizenship and Social Theory. London: Sage Publications.

Turner, Bryan S. (2000) 'Cosmopolitan Virtue: loyalty and the city', in Engin Isin (ed.) Democracy, Citizenship and the Global City. London and New York: Routledge, pp.129-48.

Vogel, Ursula and Moran, Michael (eds) (1991) The Frontiers of Citizenship. Basingstoke: Macmillan.

Walker, R.B.J. (1993) Inside/Outside: Internatinal Relations as Political Theory. Cambridge: Cambridge University Press.

Walzer, M. (ed.) (1994) Toward a Global Civil Society. Providence, RI: Berghahn Books.

Wapner, Paul (1995) 'Politics Beyond The State: Environmental Activism and World Civic Politics', World Politics, 47 (3): 311-40.

Young, Iris Marion (1990) Justice and the Politics of Difference. Princeton, NJ: Princeton University Press. 